\title{
Evaluation of geochemical anomalies detected in the Boda Claystone Formation
}

\author{
János Nádasi, Viktor Mádai, János Földessy \\ University of Miskolc, Institute of Mineralogy and Geology; H-3515 Miskolc-Campus; e-mail: janos.nadasi@gmail.com
}

(c) 2016 Authors. This is an open access publication, which can be used, distributed and reproduced in any medium according to the Creative Commons CC-BY 4.0 License requiring that the original work has been properly cited.

The Boda Claystone Formation (BCF) is a sedimentary complex researched for decades (Barabásné Stuhl 1981, Fülöp 1994, Varga 2009, Halász 2011). It was chosen the most suitable geological formation to host the high-level radioactive waste disposal (HRWD) facility in Hungary (Hámos et al. 1999, Konrád \& Hámos 2006). Since the first mappings it has been known that the reductive layers of the formation ore-indications appear (Kiss 1960). Since these were not studied, their significance is unknown. The establishment of the radioactive waste disposal facility and a possible-ore extraction are incompatible.

Our study aimed at clarifying the nature of these anomalies; assess their potential as possible economic mineralisation during the geological research for the HRWD-project.

The deep boreholes which penetrated the BCF formation encountered sulphide mineralization in certain intervals. Our evaluation is based on previous publications and reports, as well as the samples of the BAF-2 hole. The characterizations of the samples were made by macroscopically and on polished sections, in addition electron microprobe, XRD and XRF spectrometry measurements were used. A series of samples were assayed for trace element content by ICP-MS methods in the ALS Global Laboratory.

The XRF chemical analysis was used to outline the main element distribution. Applying polished section microscopy and the microprobe studies, and complemented by ICP-MS assay, we could clarify that:
- a section of the upper $100 \mathrm{~m}$ thick part of the BCF shows hydrothermal alteration effects, with $\mathrm{Cu}, \mathrm{Ag}, \mathrm{Ba}$ enrichment;

- the origin of sulfide enrichment is - epigenetic and follows the albitization period, which has been interpreted as late diagenetic process;

- in some REE minerals (monazite, xenotime) located in the microprobe samples structures suggesting remobilisation of REE occur.

Based on these observations, we assume that on the higher level anomaly in the BAF-2 drill hole the reductive geochemical zone worked as trap during at subsequent hydrothermal fluid transport. The lower anomaly of sulphide enrichment does not show relation to any significant base metal or precious metal enrichment.

It could not be verified, neither be excluded if the hydrothermal geochemical anomalies would indicate any ore mineralization of commercial grade. Further detailed sampling is warranted in the upper reductive zone to get better knowledge of the mineral assemblage and its potential economic importance.

\section{REFERENCES}

Barabásné Stuhl Á., 1981. Microflora of Permian and Lower Triassic sediments of the Mecsek Mountains (South Hungary). Acta Geologica Hungarica, 24/1, 49-98.

Fülöp J., 1994. Bodai Aleurolit formáció. [in:] Fülöp J., Magyarország geológiája. Paleozoikum II, Akadémiai Kiadó, Budapest, 353-359.

Halász A., 2011. A Bodai Aleurolit Formáció ciklussztratigráfiai vizsgálata. Pécsi Tudományegyetem. Természettudományok Doktori Iskola, Földtan Doktori Program, 10-21 [Ph.D. thesis]. 
Hámos G., Földing G., Majoros Gy. \& Konrád Gy., 1999. The role of geological research in the qualification program of the Boda Claystone Formation. [in:] The Geology of Today for Tomorrow: A Satellite Conference of the ICSU World Conference on Science: Excursion Guide Book. 23-24 June 1999, Budapest, Hungary, Budapest, 76-84.

Kiss J., 1960. Az urán-króm-vanádium eloszlása es az epigén krómcsillám szerepe a mecseki perm összletben. Földtani Közlöny, 80, 73-81.
Konrád Gy. \& Hámos G., 2006. A magyarországi nagy aktivitású radioaktív hulladéktároló telephely kijelölésének földtani szempontjai és az eddigi kutatások eredményei. Acta Geographica, Geologica et Meteorologica Debrecina, 1, 33-39.

Varga R.A., 2009. A dél-dunántúli paleozoos-alsó-triász sziliciklasztos közetek közettani és geokémiai vizsgálatának eredményei. Budapest [Ph.D. thesis]. 